\title{
Exploring functional literacy in Junior High School
}

\section{Setyawan Pujiono ${ }^{\text {a, }}$ 1* $^{*}$ Jamilah ${ }^{\text {b, } 2}$}

a Student of Language Education Science, Graduate School Program, Yogyakarta State University

b Lecturer of Language Education Science,Graduate School Program, Yogyakarta State University

Isetyawan_p@uny.ac.id ${ }^{*}$; jamilah@uny.ac.id

\begin{tabular}{l}
\hline Article Information \\
\hline Article History: \\
Submitted : 3I Dec 2020 \\
Revised : I5 March 202I \\
Published : 30 April 202I \\
\hline
\end{tabular}

Key words:

Exploration

Functional Literacy

Reading

Writing

\begin{abstract}
ABSTRAK
Kompetensi literasi menjadi kebutuhan mendasar bagi peserta didik untuk menunjang proses belajar di sekolah. Begitu pula literasi fungsional sangat penting kontribusinya untuk menjalani kehidupan bersosial dan berkomunikasi di era 4.0 saat ini. Oleh karena itu, artikel ini bertujuan untuk mendeskripsikan wujud literasi fungsional dan hambatan yang terjadi dalam pelaksanaan literasi fungsional Sekolah Menengah Pertama di Kota Yogyakarta. Metode penelitian artikel ini menggunakan studi pustaka dan pengamatan langsung implementasi literasi fungsional di sekolah. Pertama, hasil penelitian menunjukkan literasi fungsional yang diterapkan di sekolah masih sekadar pada pembiasaan membaca dan menulis. Sekolah secara umum sudah membuat program literasi seperti pos baca, kunjungan perpustakaan, pameran karya, menulis bermakna, menulis sebagai respon, pameran karya tulis, dan menulis karya. Akan tetapi, untuk implementasi literasi fungsional ke arah pengembangan, pembelajaran, dan kebutuhan fungsional peserta didik belum direncanakan serta dilaksanakan secara maksimal. Kedua, kendala implementasi literasi fungsional berasal dari diri peserta didik dan dari sekolah. Kendala yang berasal dari dalam diri peserta didik yaitu kurang motivasi, tidak fokus, lelah, dan jenuh. Kendala yang berasal dari sekolah antara lain minimnya anggaran untuk program literasi, kurangnya alokasi waktu beserta sumber referensi baru, dan belum terjalinnya kerja sama antar warga sekolah dalam pelaksanaan literasi. Pelaksanaan literasi masih bersifat topdown dan program-program literasi belum mengacu pada kebutuhan fungsional dasar peserta didik.
\end{abstract}

Key words:

Exploration

Functional Literacy

Reading

Writing

\section{ABSTRACT}

Literacy competence becomes a fundamental need for students to support their learning process at school. Likewise, the contribution of functional literacy is very important in living a social life and communicating in the current 4.0 era effectively. This article aimed to describe the form of functional literacy and the obstacles in the implementation of functional literacy program in junior high schools in Yogyakarta. This article used library research and direct observation of the implementation of functional literacy in schools as the research method. The results of the study showed that, first, functional literacy program implemented in schools was still merely accustomed to reading and writing. Schools, in general, have made literacy programs such as reading posts, library visits, work exhibitions, meaningful writing, writing as a response, writing exhibitions, and creative and academic writing. However, the implementation of functional literacy towards the development, learning, and functional needs of students has not been planned and implemented optimally. Second, the constraints on the implementation of functional literacy came from the students and the schools. In addition to the students' lack of motivation, feeling unfocused, tired, and bored also hindered the effectivity of literacy program implementation. The constraints stemming from schools included the lack of budget for literacy programs, the lack of time allocation and new reference sources, and no collaboration between school members in the implementation of literacy programs. The literacy programs were implemented using top-down approach, and have not yet referred to the basic functional needs of students. 


\section{Introduction}

Literacy can be interpreted as a daily routine related to reading and writing. In general, one interprets literacy as reading and writing activities related to language. However, literacy can also be interpreted as the competence to read and write and using the competence as a means of communication. This statement is in accordance with Teale (1986); Grabe \& Kaplan (1992); Graff (2006), who defined literacy as a person's reading and writing competence. Literacy is also interpreted as a competence in reading, writing, and mathematics (Cocchiarella, 2018). Today, literacy is interpreted in a more comprehensive manner which includes various aspects such as numerical, scientific, spatial, cultural, technological, visual and auditory, etc.

In its development, literacy skills have reached multiliterative competencies associated with everyday life (The New London Group, 2005). The concept of multiliteration is defined as the ability to use various language tools to understand information and other people's ideas in the form of conventional text as well as innovative text forms, symbols, and multimedia (Abidin, 2015). Along with the development of literacy, a new terms, functional literacy, mentioned by Cocchiarela (via Nurgiyantoro, et al. 2019) emerged. The terms and concepts of functional literacy are interpreted as competences and practical skills that are important in social life. Functional literacy can be defined as a set of information processing abilities beyond the ability to decipher and understand reading text. Functional literacy competence can be achieved if a person always applies his / her literacy skills in social life and participate in the society.

Literacy activities can be carried out anywhere, both in classroom and outside classroom. The purpose of literacy activities is to obtain various information through the process of collecting, processing, and communicating information to others. At the present, it is essential for students to be able to find and dig information through literacy activities. The competence to find information can be obtained through the activity of identifying the information needed, the ability to access various sources, the ability to evaluate information, and the ability to communicate information in life (American Library Association). This idea is in accordance with the statement from UNESCO (United National Educational Scientific and Cultural Organization) that literacy can be useful for fostering and developing personality values, ethics, and social attitudes. One will obtain life skills competencies if the values of personality, ethics, and social attitudes are always embedded and implemented in daily life. A person will get a more meaningful life purpose if he / she is able to control himself / herself in life so that there is no problem when interacting with other people.

Literacy studies are closely related to language competence which is reflected in reading, writing, and reasoning activities (Eanes, 1997). Culture and literacy habituation should be carried out from the elementary school level to the tertiary level. The result of a study on the importance of reading literacy habit from early age showed that reading habit from early age affected the level of reading competence. A child who has slow understanding process of reading since early grades will fail in the advanced class. This analysis implies that the ability to understand reading from early stage will affect further development of reading. If a child experiences difficulties in reading from the start, then the acquisition at the next stage will also be low. On the other hand, a child who gets good results in the early stages will get better results in the next stage.

Literacy practices and programs in Indonesia have been promoted through various strategies. The Indonesian government developed literacy habits with the issuance of Permendikbud No. 2I of 20I5. This program was motivated by the results of the low literacy rate in Indonesia from year to year. A survey on Indonesia's literacy culture in 1997 reported that Indonesia, in the first participation of Program for International Students Assessment (PISA), was ranked 40th out of 4I participating countries. In 2000 PISA program literacy survey, Indonesia was ranked 64th out of 65 participating countries. Furthermore, in the PISA program literacy survey in 2009, Indonesian students scored 402 in reading literacy compared to an average of 493 points in other participating countries.

Another survey related to the reading literacy of elementary school students in Indonesia is the PIRLS (Progress in International Reading Literacy Study) program where in 20I I, Indonesia was ranked 4I out of 45 participating countries. Then in 2012, Indonesia re-followed PISA study survey and was ranked 64 out of the 65 participating countries. Indonesia experienced an increase in literacy skills in 2015, ranking 62 out of 70 participating countries. Then, in 2018 PISA survey, Indonesian students scored a mean score of 37I points compared to an average score of 487 in other participating countries. China won first place with a score of 555, followed by Singapore in second place with a score of 549, and third place was Macau with a score of 525 (OECD, 2019). Based on the results of the survey above, the Indonesian government under the command of the Ministry of Education and Culture (Kemendikbud) on August 182015 held a literacy culture program through schools entitled Gerakan Literasi Sekolah (School Literacy Program) with the theme Language Builds Character.

The Ministry of Education and Culture (2019) followed up on the reading literacy program in Indonesia through the Alibaca (Reading Literacy Rate) program. This program aimed to measure the reading skills of 
Indonesian children in terms of skill, access, alternative, and cultural domains. The survey was conducted in 34 provinces in Indonesia. The results of these measurements showed that; first, nine provinces (26\%) were reported to have moderate literacy activity. Second, it was found that 24 provinces in Indonesia (71\%) were in the low literacy level. Finally, one province (3\%) was considered as having very low literacy level. Based on these measurements, it can be interpreted that literacy activities in all major regions in Indonesia were in the low level, and not even one province was in the category of high-level literacy.

Based on the results of the survey or measurement of PISA and PIRLS programs on literacy in Indonesia, the government has been aggressively programming a literacy movement since 2015. The implementation of literacy programs is prioritized for children and adolescents in primary and secondary schools. However, the literacy program at the advanced level is still implemented because Indonesian students' reading literacy rate is still low according to the results of PISA survey. Mansyur (2020) stated that the high or low reading interest of students is certainly closely related to their ability to process information in an analytic, evaluative, and creative manner, which is currently known as HOTS (Higher Order Thinking Skill). Low ability and motivation will result in the low competency of students' critical and creative thinking.

Instilling interest and love for literacy activities can be done through implementing functional literacy. Functional literacy can be carried out through various cultural reading and writing activities related to social and cultural life. This is what will encourage students to always be motivated in literacy. Various techniques and efforts to build a culture of functional literacy can be implemented in schools, at home, and in the community. Functional literacy culture is carried out continuously in accordance with the conditions and needs of everyday life. Therefore, the success of cultivating functional literacy will affect a person's success in living his current social life. This article discusses how far the implementation of functional literacy in students has been carried out in junior high school.

\section{Method}

This study was conducted by reviewing relevant literature and observing the implementation of literacy program in Junior High School (SMP) in Yogyakarta City. Observations regarding the implementation of functional literacy programs were conducted at SMP Negeri 5 and SMP Negeri 8 Yogyakarta before the COVID19 Pandemic. The two junior high schools were chosen as research sites because these schools are high-ranked junior high school with many achievements in both academic and non-academic fields. Observations were performed to see concretely what literacy programs were carried out in the two schools.

Library research was conducted by examining the theory related to the research problem, namely functional literacy. Library research is the presentation of scientific reasoning arguments from the results of literature reviews and the ideas of the researchers related to the topic or focus of the theory. The research was conducted through a critical study of various relevant theoretical sources supported by theoretical research results from articles in journals and previous research. Various sources of literature were used to obtain a basis for acquiring new ideas. The literature study of theory involved a process of deduction from previous knowledge. The results can be used to develop a theoretical framework and a basis for solving research problems.

The sources of theory related to the research problem were examined in order to describe and discuss the research problem. The sources of theory were obtained from books, articles, and literacy guides from the Ministry of Education and Culture related to functional literacy, six basic literacy programs, and the application of literacy in school. Literature sources also included the theory contained in published journal articles. Reference of citation sources to support this research were sourced from textbooks, scientific journals, guidebooks, research reports, theses, dissertations, and sources from the internet. The research data were collected through literature review and direct observation at school. We conducted in-depth evaluation and analysis on the sources of theory that were relevant to the formulated research problem. The results of the study were written and presented descriptively in a logical and systematic manner. Library research is useful for the development of a theory as a basis for the research conducted (Sujarweni, 20I4).

\section{Result and Discussion}

\section{The Basic Concept of Literacy Program}

The legal basis for implementing literacy programs in Indonesia can be seen starting from the 1945 Constitution, Article 3I, Paragraph 3 which reads "The government organizes and implements a national education system, to be regulated by law, that aims at enhancing religious and pious feelings as well as moral excellence with a view to upgrading national life". This verse implies that school institutions have the responsibility and obligation to carry out programs aimed at educating the nation's children and to develop the kind of intelligence that enables all school members to have ethical, spiritual, emotional, intellectual, language, artistic, and social intelligence to support their lives on a regional, national, and international scale. 
The government has also issued a Regulation of the Ministry of Education and Culture (Permendikbud) Number 23 of 2015 concerning Character Building. One of the activities included is the habituation of 15 minutes reading before learning begins in the primary and secondary school level. This government program is supported and strengthened by the implementation of Gerakan Literasi Sekolah (School Literacy Program). The GLS program from the government spearheaded by the Ministry of Education and Culture aims to cultivate and foster the reading habits of students in school. With a good reading habits, students will get a variety of information that can be used to support learning at school or support their life at home or in the community. Students will also be able to use the various sources of information they get to face all the challenges of life in today's destructive era.

As a follow-up to the implementation of the 1945 Constitution and Permendikbud Number 23 of 2015, all schools from the level of Elementary School, Junior High School, and Senior High School in Indonesia are required to implement the GLS program. This program is useful for all school members in developing and fostering reading culture. The success of the GLS program, certainly, cannot be separated from the participation and support of parents or families at home and in the community. Therefore, in October 2017, the government launched a follow-up program called Gerakan Literasi Nasional (National Literacy Program). This program was designed based on the improvement from the previous program which have not been evenly implemented in all regions in Indonesia. The GLN is implemented in all regions in Indonesia with the aim of cultivating reading habit as well as strengthening character education. This is in accordance with the stipulation of Permendikbud Number 20 of 2018 concerning Strengthening Character Education in Formal Education Units.

The literacy program is also used as one of the aspects in the Graduate Competency Standards (SKL) component assessed by the National Accreditation Board for Secondary Schools (BAN SM) Number 33. This item assesses habituation activities through the GLS program which includes planning and evaluating literacy programs, providing adequate time allocation for literacy implementation, reading books, literacy-related competitions, displaying literacy work, literacy development training, and awarding students and schools. Each school is willing to implement and succeed the literacy program in its respective schools. Then, texts that support literacy can be grouped into three types of which students often meet such texts in daily life. The three types of the text are (I) narrative prose text which contains story of both fact and fiction; (2) expository prose which contains expositions, descriptions, explanations or factual opinions; (3) documents that present information through diagrams, tables, maps, charts, lists, or instructions (Muhammadi, Taufina and Chandra, 2018).

\section{Basic Literacy Program from the Ministry of Education and Culture}

Through the Ministry of Education and Culture, the government has been promoting the GLS program since 20I5. However, before the GLS program was implemented in Indonesia, there were private institutions that had collaborated with schools and implemented literacy programs. This institution was USAID Prioritas, an educational grant aid agency for Indonesia from the United States. USAID Prioritas conducted various literacy programs from primary to secondary school levels in 33 provinces in Indonesia. Based on these USAID activities, the Ministry of Education and Culture developed GLS program in 20I5. Today, the development of literacy in Indonesia has reached a stage where a six basic literacy program aimed at functional literacy was launched. The six basic literacy are reading and writing literacy, numeracy, science, finance, digital, culture and citizenship (Kemdikbud, 2017). The implementation of the six basic literacy in school, at home or in the community will be described as follows.

First, the function of reading literacy is to understand written information, either directly or indirectly, and use the information to develop students' knowledge and self-potential. Written literacy is useful for expressing ideas that are presented coherently in written language to support daily life activities. Thus, reading and writing literacy is very important for the process of learning and getting knowledge, enriching vocabulary mastery, increasing creativity, practicing concentration, fostering interest in new things, and reducing the level of boredom or stress. The application of reading and writing literacy should be done in school, at home, and in the community.

Literacy programs that can be implemented in school are for example reading books before lesson begins, writing book review, and building class library. Literacy programs that can be implemented at home by parents include: reading stories to children, reading with family, educational games, writing letters to families, telling interesting family stories, and building a family library. Literacy programs that can be carried out in the community include storytelling competitions, literacy festivals, literacy villages, and village reading corners.

Second, numeracy literacy serves to improve mathematics skills. This skill aims to improve the skills of students in using various kinds of numbers and symbols as well as the competence in analyzing tables, graphs, charts and so on. The first skill involves using various kinds of numbers and symbols in basic mathematics to solve problems that occur in everyday life. The second skill includes the ability to analyze tables, graphs, and charts as a basis for predicting or making decisions regarding a problem. 
Numerical literacy activities that students can do at school are for example, measuring body weight, height, age of students, designing school plans, making home to school road routes, and making prototypes of bridges or houses. At home, students can do activities such as calculating the distance traveled when traveling, drawing house plans, and measuring ingredients for food recipes. For numeracy activities in the community, some activities students can do are collecting data on residents in the neighborhood area, making house boundaries, calculating household waste production, and so on.

Third, scientific literacy aims to cultivate the skills of understanding natural and social conditions and phenomena in the environment. Science skills can also be in the form of scientific decision-making abilities to lead a healthier and better lifestyle. Science literacy aims to enable students to obtain and select appropriate scientific information, understand images, analyze tables and charts, and provide an assessment of the correctness of the information. Scientific literacy activities that can be performed at school are caring for, observing, and reporting plant growth. At home, some of the scientific literacy activities students can do include growing plants, cooking and discussing the nutritional content of food, and reading information on healthy lifestyles at home. Then, the scientific literacy activities students can do in the community are community service in the neighborhood, growing medicinal plants, and taking good care of pets.

Fourth, economic or financial literacy refers to the ability or skills to apply an understanding of financial concepts, risks, and motivation. Economic literacy is useful for increasing financial income both individually, socially, and for the surrounding community. Financial literacy activities that can be done at school are, for example, familiarizing students with shopping at school cooperative, practicing money saving, and understanding transactions in the market. Financial literacy activities at home, are, for example, managing pocket money and getting into the habit of saving money. Financial literacy activities in the community include knowing the prices of basic commodities and social security funds (BPJS).

Fifth, technology or digital literacy aims to increase the abilities and skills of students in using digital media responsibly in obtaining information and communication. Technological literacy will train students to think creatively, innovatively, and communicatively in interacting with others through technology. Students will easily establish interactions and expand collaboration with more friends by using technology.

Digital literacy strategies in school include providing and using online classes so that students can learn any time they want and providing material, information, and services for students using digital technology tools. Gilster (I997) stated that digital literacy is the ability to understand and use various material sources that can be obtained through computers. Digital literacy activities in the family are, for example, making family documentation (photos and videos), exploring (browsing) information on the internet, and looking for materials to support school lessons. Then, digital lliteracy activities in the community include using the internet for social fundraising, looking for jobs, and entrepreneurship.

Sixth, cultural literacy is a person's ability to understand, appreciate, and respond to culture as a treasure of national identity. It is also related to civic literacy or instilling students' understanding regarding their rights and obligations as Indonesian citizens. Therefore, cultural and civic literacy activities that can be carried out at school are visiting cultural places, knowing the process of making family cards, ID cards, BPJS (Healthcare and Social Security Agency) and SKCK (Police Certificate of Good Conduct). Cultural and civic literacy activities at home are, for example, studying in museums, traveling to historical places, visiting temples, visiting neighborhood offices, sub-district offices, and police stations. Cultural and civic literacy activities in the community include developing a community reading garden, being active in the TPA, and having discussions with other residents.

\section{The Implementation of Functional Literacy Program in School}

Basically, the six basic literacy programs launched by Kemendibud have already led to functional literacy. However, there are several aspects related to functional literacy that have not been implemented in school. The reason is that in implementing literacy, school still strictly followed the references and guidelines from the government. School has not dared to take breakthrough to implement literacy programs that truly suit the needs of students and the school environment. Kamil (2020) stated that functional literacy requires two things, namely: I) the ability to utilize literacy in various lines of life and 2) the ability to apply literacy for understanding, change, and self-correction towards the changing world. Functional literacy is defined as the competence and practical skills needed to effectively function in social life.

The ability of functional literacy contributes to the changes in a person to foster a virtuous attitude, solidarity, and love for preserving culture. The habit of functional literacy will indirectly increase a person's 
sensitivity to be able to choose good information, to be critical and creative, and to live a humane life. Personal skills will also be well formed during the process of extracting and obtaining information.

Students who already have functional literacy skills can apply their basic knowledge and skills in social life. Every student needs literacy competencies to support their role in society. The stages of literacy implementation that have been carried out in schools are elaborated as follows. Widarti, et al. (2016:28) described the three stages of implementing the GLS as follows. The first stage is the habituation of fun reading activities at school. Cultivating reading culture at school aims to increase reading interest and reading habits in students or all school members. The second stage is developing motivation or interest in reading to improve literacy competencies. The purpose of doing activities at this stage is to develop reading comprehension skills that is linked to students' personal experiences. Further, it aims to train students to relate their personal experiences with reading so that the end result is productive activities in written or oral form. The third stage is literacy-based learning. The literacybased learning stage aims to familiarize students with reading various fields of knowledge based on their personal experiences. The third stage is oriented to support the implementation of 2013 Curriculum which requires students to read non-textbooks.

The implementation of literacy programs will be effective if they are carried out at school or in the community. Tungka, (2018), stated that "Literacy education focuses on the construction of meaning tied to social contexts". The context of literacy education focuses on the construct of understanding meaning that can be applied in the community. Literacy education can be cultivated through programs such as the habituation of reading and writing. However, sometimes, the concept of functional literacy has not caught the attention of literacy activists. The concept of functional literacy can be interpreted as the competence and practical skills needed to effectively function in social life. Therefore, the implementation of functional literacy can be carried out through habituation, development, and learning reading and writing in schools.

Banat and Pierewan (2019) stated that reading literacy can predict the academic achievement regarding knowledge but not the academic achievement in terms of skills. Related to this, there are five aspects concerning why literacy focuses more on reading and writing competencies. First, readers attempt to organize and construct meaning. Therefore, every good reader must have a purpose. This goal moves the reader's mind to relate it to the content of the text according to the experience they have. Second, reading and writing are competencies that can naturally grow together. Both activities go through the same process involving the aspects of knowledge. Third, reading and writing activities can be used together to gain achievement. Writing activities will drive someone to be skilled at reading, then reading activities will motivate someone to be skilled at writing. Fourth, both reading and writing will improve communication skills. Fifth, the combination of reading and writing motivates one's thinking ability.

According to Beers (2009), good practice in the GLS program emphasizes principles such as (I) the mastery of literacy competencies develops according to predictable stages; (2) the implementation of literacy programs in schools must be proportional to the needs of students, which of course varies from person to person; (3) integrating literacy with the curriculum used in schools; (4) the habit of reading and writing is carried out continuously until it becomes a culture; (5) literacy programs will improve the ability to obtain correct information as a means of communication; (6) literacy programs are aimed at developing solidarity towards differences or diversity.

Various literacy cultures can be self-created and self-named. An important factor in literacy habituation is the acculturation of reading and writing skills which must be done not only occasionally, but continuously and becomes a culture for students. There are also objectives to be achieved with this literacy culture, both related to the learning process and outside of learning. Functional literacy is an important goal because it is essential practical skill needed in social life. The continuity of functional literacy activities aims to achieve habits / culture and become a necessity for students in supporting learning in schools and social communities.

Students do not acquire writing competence by themselves because there are critical and creative thinking activities in the process. Writing is an activity of processing information based on experience and knowledge presented in written language. Writing can be useful for putting all the experiences and ideas one has into an orderly and coherent series of writing. Students who are accustomed to writing will have broad knowledge and make their experiences meaningful for themselves or their readers.

The habit or culture of reading literacy has been implemented in junior high schools in Yogyakarta City. The names of literacy programs implemented in the schools were different, but in principle, they were almost the same. Literacy programs that have been implemented in schools included (I) Silent Reading, (2) Reading Quizzes, (3) Reading Stories, (4) Reading Posts, (5) Reading with Prizes, (6) Library Visits, (7) Reading Portfolios, etc. The writing literacy program carried out in schools included (I) Writing Is Fun, (2) Meaningful Writing, (3) Writing as a Response, (4) Brainstorming Ideas, (5) Exhibition of Works, (6) My Diary, and so on. 
Based on the literacy programs above, it appears that functional literacy program has not been effectively implemented in schools. The programs implemented have not referred to the basic functional needs of students. The students' needs should become the main reference in functional literacy program. Thus, so far, literacy programs in schools were still implemented using top-down approach and have not met the basic functional needs of students which support the needs of schools and community social life.

Functional literacy program in school needs to be formulated by school principal, teachers, library manager, students, and all school members who know the real condition of students and their environment. Khuzaemaha, et al. (2018) stated that teachers can develop students' enthusiasm and literacy awareness in learning using techniques and methods that are in accordance with the characteristics of students and the condition of the school environment. In addition, functional literacy programs such as health, transportation, environment, mitigation, learning styles and technology have not been implemented in schools. The effort that needs to be done so that students have a literacy culture is to prepare supporting facilities and teachers and literacy activists who are ready to teach it (Sari and Pujiono, 2017).

Kern, (2000) formulated the following principles in teaching or cultivating literacy. I) Literacy involves different interpretations between readers and writers according to their respective worlds. 2) Literacy forms a collaborative character, namely cultivating cooperation to obtain the same meaning. 3) Literacy imparts cultural knowledge related to values, beliefs, behavior, ideals and beliefs. 4) Literacy fosters a sense of kinship and social relations with the surrounding environment. 5) Literacy is not only a language activity but also requires knowledge in order to be able to communicate both orally and in written form to create a discourse.

\section{The Obstacles in Implementing Functional Literacy Program in School}

The constraining factor for the implementation of functional literacy program in junior high schools in Yogyakarta is the budget policy that has not been specifically allocated; lack of cooperation between literacy activists in schools such as librarians, teachers, and school employees; and ineffective time allocation for literacy program implementation.

First, in general, the budget for the GLS program comes from BOS funds. The budget for literacy programs has not been specifically allocated to support all literacy activities. The school budget was allocated for general literacy programs such as book procurement, publication of children's literacy results, and infrastructure maintenance. For example, teachers or school literacy activists must seek sponsors to support the implementation of activity for the School Literacy Olympic. Besides that, there has not been a special budget for publication costs for students who wants their works to be published or rewards for students. This is due to the limited funds available. This made it difficult for schools to create new programs. Finally, schools allocated the minimum possible funding in implementing school literacy program.

Second, it is important for all school members to play an active role in the implementation of the GLS program. Each party need to be committed to the program. Without the cooperation of all school members, the implementation of the GLS program will not go well. Collaboration between school principals, teachers, employees, librarian, and student guardians is needed for the implementation of literacy programs in school. In addition, the support and cooperation from the regents / mayors, the education office, and school committees are very important for the sustainability of literacy programs. Research by Muslimin (2018) reinforced the notion that familiarizing literacy requires a program strategy, provision of facilities, and support from all community.

Third, the next problem is the allocation of time for the implementation of literacy programs. The time allocation for students in school is still oriented towards learning according to the 2013 curriculum. Teachers and school literacy activists have not developed literacy activities in the learning process. Even if there is literacy activity, the time is very limited. For example, the 15 minutes reading program before learning and filling the reading journal afterwards is still inadequate. I5 minutes reading is thought to have not produced the best essence of literacy. The I5 minutes time allocation for reading and writing is very insufficient for understanding the contents of the book. Basically, literacy does not only mean being able to read and write, but also to produce works.

Functional literacy can be said to be carried out well if it meets the following criteria. I) The culture of reading and writing is carried out massively by all circles in the school, not only students and teachers. 2) Books and reading sources are abundant in schools and can be read by all school members. 3) The birth of various kinds of innovative works from students (the works are not due to duty or coercion but awareness and need). 4) Increased 4C abilities (critical, creative, communicative, collaborative). 5) Literacy programs in school are tailored to the needs of students and support daily life, including digital literacy, documents, environment, health, transportation, politeness, culture, social, and mitigation. 


\section{Conclusion}

Functional literacy competencies are very important for students to effectively live and function in the community in the 2Ist century. Therefore, this article describes the manifestation of literacy and the obstacles that occurred, especially in the implementation of functional literacy program in Junior High Schools in Yogyakarta. The results of the first formulation of the research showed that literacy program implemented in schools was still focused on reading and writing habituation. Literacy programs implemented in schools included reading post, library visits, work exhibitions, meaningful writing, writing as a response, writing exhibitions, and creative and academic writing. The implementation of functional literacy program in schools that leads to the development, learning, and functional needs of students has not been planned and implemented optimally. This can be seen from the observation that schools have not planned and programmed functional literacy specifically. The literacy implemented was merely a reading and writing literacy program. Meanwhile, functional literacy prograk can be carried out through various cultural reading and writing activities related to the social and cultural life of students.

Second, the obstacles in the literacy program implementation came from the students and the school management. In addition to the students' lack of motivation, feeling unfocused, tired, and bored also hindered the effectivity of literacy program implementation. Meanwhile, the constraints from the schools included the lack of budget for literacy programs, insufficient time allocation and new reference sources, and no collaboration between school members in the implementation of literacy. The literacy programs were still implemented using a top-down approach and have not yet referred to the basic functional needs of students. Basic literacy program has been implemented in junior high schools, but functional literacy program has not been planned and implemented optimally. Therefore, functional literacy needs to be socialized to schools so that teachers and literacy activists can compile functional literacy programs to support the lives of students in the 2Ist century today.

\section{Acknowledgment}

We would like to express our appreciation to all colleagues who were willing to assist us in writing this research article. Our grateful thanks are also extended to the reviewers and managers of Bahastra journal for reading and reviewing this article, and finally for the consideration of publishing this article.

\section{References}

Banat, S. M. dan Pierewan, A. C. (2019). Reading Literacy and Metacognitive Strategy For Predicting Academic Achievement. Litera, Jurnal Penelitian Bahasa, Sastra, dan Pengajarannya, I8 (3), 485-497. https://journal.uny.ac.id/index.php/litera/issue/view/I775

Beers, C. S., Beers, J. W., \& Smith, J. O. (2009). A Principal's Guide to Literacy Instruction. New York: Guilford Press.

Clay, M. M. (200I). Change Over Time in Children's Literacy Development. Portsmouth: Heinemann.

Cocchiarella, C. (2018). What is Functional Literacy, anda why does our high-tech society need it? Dari https://mindfultechnics.com/what-is-functional-literacy/.

Eanes, R. (1997). Content Area Literacy: Teaching for Today and Tomorrow. Washington: ITP An International Thomson Publishing Company.

Gilster, P. (I997). Digital Literacy. https://www.amazon.com/Digital-Literacy-Paul-Gilster/dp/047I24952I

Grabe, W. \& Kaplan R. ed. (1992). Introduction to Applied Linguistics. New York: Addison-Wesley Publishing Company.

Graff, H. J. (2006) Literacy. Microsoft Encarta. Redmond, WA: Microsoft Corporation.

Gujjar, A. A. (20I4). Literacy: a Foundation for Development of Society, http://www.eslteachersboard.com/cgibin/, accessed 2014

Hartati, Marni, dkk. (2019). Gerakan Literasi Sekolah (GLS) di SMA. Jakarta: Direktorat Pembinaan Sekolah Menengah Atas Kemdikbud.

Kamil, M. (2020). Literasi Global (Global Literacy). Dari http://file.upi.edu/Direktori/ Presentation_Keaksaraan_fungsional_solo.pdf.

Kemdikbud. (2020). Buku Panduan Merdeka Belajar-Kampus Merdeka. Jakarta: Direktorat Jenderal Pendidikan Tinggi.

Kemdikbud. (2017). Pedoman Penilaian dan Evaluasi Gerakan Literasi Nasional. Jakarta: Kementerian Pendidikan dan Kebudayaan.

Kemdikbud. (2017). Materi Pendukung Literasi Baca Tulis. Jakarta: Kementerian Pendidikan dan Kebudayaan. Kemdikbud. (2016). Pedoman Pelaksanaan Gerakan Nasional Literasi Bangsa. Jakarta: Badan Pengembangan dan Pembinaan Bahasa Kemdikbud. 
Kern, R. (2000). Literacy and Language Teaching. Oxford: Oxford University Press.

Khuzaemaha, E., Herawatia, L, Ummi, H. U. (2018). Model Pendidikan Literasi dengan Menggunakan Pendekatan Saintifik. Jurnal ILEAL (Indonesian Language Education and Literature). Volume 3 Nomor 2. 227-239. https://www.syekhnurjatiac.id/jurnal/index.php/jeill/issue/view/234.

Mansyur, U. (2020) Minat Baca Mahasiswa: Potret Pengembangan Budaya Literasi Di Universitas Muslim Indonesia. Literasi, Jurnal Penelitian Bahasa dan Sastra Indonesia serta Pembelajarannya, Volumen 4 (2), I35-I4. https://jurnal.unigal.ac.id/index.php/literasi

Mullis, I. V. S., dkk. (20II). PIRLS-International Results in Reading. http://doi.org/I0.1097/0I.tp.0000399132.51747.7I.

Muslimin. (2018). Foster a Culture of Literacy Through Increased Reading Interest in Village Communities. Cakrawala Pendidikan, Jurnal Ilmiah Pendidikan. Edisi Februari, Nomor I, I07-II8 https://journal.uny.ac.id/index.php/cp/issue/view/I500.

Muhammadi, T. dan Chandra. (2018). Literasi Membaca untuk Memantapkan Nilai Sosial Siswa SD. Litera, Jurnal Penelitian Bahasa, Sastra, dan Pengajarannya, Fakultas Bahasa dan Seni UNY Volume 17, Nomor 2, Juli 2018.

Nurgiyantoro, B., Lestyarini, B. dan Rahayu, D. H. (2020). Konstruk Asesmen Literasi Fungsional untuk Sekolah Menengah Pertama. Litera, Jurnal Penelitian Bahasa, Sastra, dan Pengajarannya, 19 (2), 210-227. https://journal.uny.ac.id/index.php/litera/issue/view/I9IO.

Patton, M. Q. (2014). Qualitative Research \& Evaluation Methods: Integrating Theory and Practice. New York: SAGE Publications.

Sari, E. S. \& Pujiono, S. (2017). Budaya Literasi di Kalangan Mahasiswa FBS UNY. Litera, Jurnal Penelitian Bahasa, Sastra, dan Pengajarannya, 16 (I), I05-II3. https://journal.uny.ac.id/index.php/litera/article/view/I4254/944I.

Sujarweni, V. W. (2014). Metodologi Penelitian. Yogyakarta: Pustaka Baru Press.

Teale, William H., Sulzby, Elizabeth. (1986). Emergent Literacy: Writing and Reading: Ablex Publication Corp. University of Minnesota

The London Group. (2005). A Pedagogy of Multiliteracies: Designing Social Futures. Yara: Macmillan (pp. 938).

Tungka, N. F. (2018). Guided Literacy Instruction: Helping Students Read Multimodal English-medium Texts. IJAL, Indonesian Journal of Applied Linguistics, 8(2), September 2018.

Wiedarti, P. dkk. (2019). Gerakan Literasi Sekolah. Direktorat Jenderal Pendidikan Dasar dan Menengah Kementerian Pendidikan dan Kebudayaan. 